\title{
Inalienable possession in Iquito (Zaparoan): a frequency analysis*
}

\author{
Cynthia I. A. Hansen
}

Some languages exhibit differential marking between inalienable possession and alienable possession (Nichols 1988, Heine 1997). Inalienable constructions, which indicate possession that is "inborn, inherent, not conferred by purchase" (Nichols 1988: 568), tend to be zeromarked or marked with very short coding. This coding is often bound and can also be obligatorily marked. In contrast, alienable constructions, which indicate possession that is "ownership, socially and economically conferred" (Nichols 1988: 568), tend to show overt coding that is longer and not bound.

An iconicity approach explains this difference in coding by arguing that there is a closer conceptual link between a possessor of an inalienably possessed object than between a possessor and an alienably possessed object (Haiman 1983: 783). This conceptual link is iconically represented by using shorter linguistic forms for marking inalienable possession. A frequency approach argues that the coding asymmetry correlates with a universal frequency asymmetry, meaning that inalienable nouns are possessed relatively more frequently within a corpus than are alienable nouns, and frequently occurring items are more likely to have shorter linguistic forms (Haspelmath 2008).

This paper looks at the marking of inalienable possession in Iquito, a highly endangered Zaparoan language of the northern Peruvian Amazon, and presents data in favor of Haspelmath's (2008) analysis, by showing that the shorter, more cohesive forms found with inalienably possessed nouns are better explained by frequency of use than by iconicity.

Iquito is one of the three remaining languages of the Zaparoan family, together with Arabela (about 75 speakers) and Záparo (1 to 3 speakers). It has about 25 fluent native speakers, all over the age of 55 and all bilingual with Spanish. The majority of these speakers live in the community of San Antonio del Pintuyacu, in the state of Loreto, Peru, about 100 kilometers west of the city of Iquitos.

Extensive linguistic fieldwork has been conducted by members of the Iquito Language Documentation Project (ILDP), a project made up of a team of linguists from The University of Texas at Austin and the Universidad Nacional Mayor de San Marcos in Lima, Peru working in collaboration with members of the community. The ILDP has been largely funded by the Endangered Languages Documentation Programme of the Hans Rausing Endangered Languages Project, and more information can be found at http://www.cabeceras.org/ indexiquito.html.

\footnotetext{
${ }^{*}$ Special thanks are in order to the Iquito speakers that I have worked with: Hermenegildo Díaz Cuyasa, Ligia Inuma Inuma, Jaime Pacaya Inuma, and Ema Llona Yareja. I also thank my colleagues from the Iquito Language Documentation Project for their support and insight and Martin Haspelmath for providing comments at the initial stage of this paper.
} 
The Iquito data presented in this paper is the result of fieldwork that I conducted from June to November of 2006 as a member of the ILDP and from a second solo trip in the summer of 2008.

Iquito exhibits an alienability split, where inalienable nouns fall into the following semantic domains: kinship terms, human and animal body parts, ${ }^{1}$ plant parts, part-whole relationships, and items closely related to humans and animals (e.g. cujímani 'companion', ‘́yaaca 'name', junïni 'smell, breath', naáqui 'egg', and najuhuáaca 'coloring, pattern (of an animal)'). These semantic domains align with the ones most likely to be marked as inalienably possessed cross-linguistically (cf. Nichols 1988: 568). All other nouns fall into the alienable class.

There are two strategies for marking possession in Iquito, both of which can be used with inalienable and alienable nouns. The first strategy is to juxtapose two nouns, where N1 N2 corresponds to Possessor Possessum, as shown in (1). The second strategy is to add a possessive prefix to the possessed noun, as shown in (2).
a. icuáni namíja (Inalienable)
man eye
'man's eye'
b. icuáni iímina (Alienable)
man canoe
'man's canoe'

a. nu-namíja (Inalienable)
3sG-eye
'his/her eye'
b. nu-iimina (Alienable)
3sG-canoe
'his/her canoe'

In languages that make an inalienable/alienable distinction, one strategy is usually reserved for the inalienable nouns and the other strategy is used with alienable nouns, but this is not the case in Iquito. Instead, the distinction is marked in two other ways. First, inalienable possession is obligatorily marked, and alienable possession is not. Second, there are morphophonological processes that occur when inalienable nouns are possessed that are absent with alienable nouns.

One of these processes is a form of vowel hiatus resolution that occurs when the third person singular possessive prefix nu- is added to nouns beginning with a or aa. With alienable nouns, the vowel of the prefix is preserved, even in fast speech, but with inalienable nouns, nu- is reduced to $n-$, as shown in Table 1.

Table 1 also illustrates a vowel hiatus resolution pattern that occurs when the third person singular possessive prefix $n u$ - is added to nouns that begin with the vowels $i$ and ii. Under

\footnotetext{
${ }^{1}$ The only known exceptions are majaaca 'blood' and niiqui 'bone', which occur both possessed and unpossessed in texts. This finding is not particularly surprising in a hunting society.
} 
Table 1: Examples of vowel hiatus resolution with inalienable nouns and 3SG possessor

\begin{tabular}{|c|c|c|c|}
\hline INITIAL VOWEL & EXPECTED FORM & REDUCED FORM & GLOSS \\
\hline $\mathrm{a}$ & nu-ánaca & nánaca & 'his/her/its head' \\
\hline & nu-áquica & náquica & 'its branch (of a tree)' \\
\hline & nu-atamajáti & natamajáti & 'her sister' \\
\hline aa & nu-áaja & náaja & 'his/her/its leg/thigh' \\
\hline$i$ & nu-íniija & níniija & 'its seed/fruit' \\
\hline & nu-íraaca & níraaca & 'its wattles' \\
\hline & nu-ísłqqu̇ & $n \dot{x} \operatorname{siqu\dot {x}}$ & 'its peel/skin' \\
\hline ii & nu-iíca & nisbica & 'his/her/its tooth' \\
\hline
\end{tabular}

this pattern, the vowel of the prefix coalesces with the initial vowel of the inalienable noun. With alienable nouns, the vowel of the prefix is preserved, even in fast speech.

These processes are only seen with inalienable nouns and are not found with nouns from the alienable subclass. For instance, nu-iita 'his/her/its house' cannot be pronounced as *níta, despite the similar phonological shape to the word for 'tooth' given in Table 1 . Furthermore, the vowel hiatus resolution patterns seen with the inalienable nouns are used with some variation; speakers will use either the expected or the reduced form in both careful and rapid speech. As a result, when we see the reduced form, we can infer that a noun is inalienable, but we cannot make predictions about a noun's alienability status if it occurs in the expected form.

The final morphophonological process is not a type of vowel hiatus resolution, but rather a change in stem vowel quality. It occurs with a limited set of inalienable nouns beginning with the syllable ni: -níyaaca 'husband', -niyíni 'son', and -niyíti 'daughter'. When these nouns are possessed in the third person singular, there is a vowel quality change on the first syllable: ni becomes ni as shown in Table 2. Unlike the vowel hiatus resolution patterns described above for inalienable nouns, there is only one allowed form; no alternation exists with nu-. Additionally, I have only found these three nouns to undergo this change; with all other inalienable nouns, the third person singular prefix nu- is prefixed to the noun, even if they also begin with the syllable ni (see Table 2). For these nouns, the reduced form is ungrammatical, even though they are inalienable. With alienable nouns, the third person singular prefix $n u$ - is prefixed to the noun, as expected.

This data from Iquito supports the generalization that possessive affixes with inalienable nouns tend to be shorter than those with alienable nouns (Haiman 1983, Nichols 1988, Haspelmath 2008), but an iconicity analysis is problematic for the last morpho-phonological process for two reasons. First, under such an analysis, we would not expect differential marking to be dependent on the person of the possessor. Second, we would expect all inalienable terms that exhibit the conditions for the merger to undergo this phonological 
Table 2: Examples of vowel quality changes with inalienable nouns and 3sG possessor

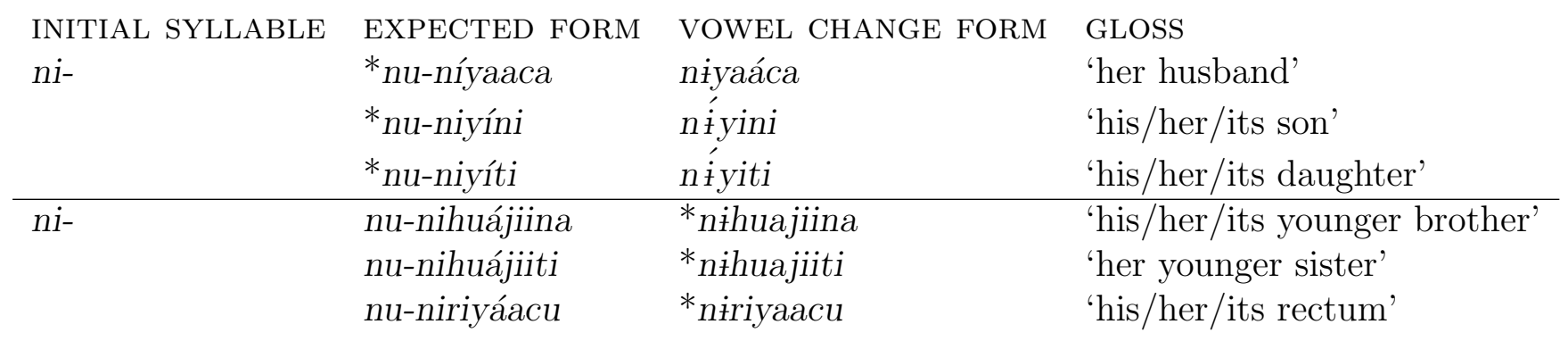

process, since conceptual closeness should not vary within the class of inalienables.

A frequency account, however, does account for these differences. The three terms that undergo the vowel quality change process are arguably more frequent than other kinship terms. Although the corpus of Iquito textual data is too small to determine relative frequency of these terms, it does include over 800 instances of possession. Kinship terms are the most frequently possessed, and thus it is not surprising that there is differential marking for kinship terms that is not consistently found with other inalienably possessed nouns like body parts or part-whole relationships.

Although an iconicity account captures the observation that the inalienable form is shorter than the alienable form, only a frequency account captures the irregularity with the inalienable nouns. Frequency can also be used to explain shortness of form, so it is the more robust explanation.

\section{References}

[1] Haiman, John. 1983. Iconic and economic motivation. Language 59.4:781-819.

[2] Haspelmath, Martin. 2008. Frequency vs. iconicity in explaining grammatical asymmetries. Cognitive Linguistics 19.1:1-33.

[3] Heine, Bernd. 1997. Possession: Cognitive forces, sources, and grammaticalization. Cambridge: Cambridge University Press.

[4] Nichols, Johanna. 1988. On alienable and inalienable possession. In In Honor of Mary Haas. William Shipley, ed. Berlin: Mouton de Gruyter, pp. 557-609. 